\title{
Context and historical (socio-)pragmatics 20 years on
}

\author{
Dawn Archer \\ Manchester Metropolitan University
}

\begin{abstract}
This paper has two purposes. First, it constitutes an exploration of context from the perspective of some prominent historical pragmaticians, and/or as demonstrated by representative publications which exemplify a particular approach within historical pragmatics (Jacobs and Jucker, 1995; Archer and Culpeper, 2003, 2011; Nevala, 2011; Jucker and Taavitsainen, 2014; Traugott, 2004, 2011; 2012) as well as related disciplines such as historical sociolinguistics (Nevalainen and Raumolin-Brunberg, 2003). Second, it explores my own (evolving) view in respect to context, often in response to the influential work of others; as evidenced in a selection of my work (Archer, 2005, 2011, 2012, 2013, 2014).
\end{abstract}

Keywords: academic positioning, context(s), corpus linguistics, decontextualisation and recontextualisation, mental aspects

\section{Introduction}

1995 is a very important year when it comes to the discipline of historical pragmatics, not least because it was the year that the edited volume of the same name appeared; and that particular edited volume is now regarded by many as having kick-started the discipline proper. Nearly twenty years on, this paper explores Jacobs and Jucker's (1995) introduction within Jucker's (ed.) Historical Pragmatics and 11 additional publications representative of different expressions of the historical pragmatics discipline (Archer and Culpeper, 2003, 2009; Traugott, 2004, 2011, 2012; Nevala, 2011; Archer, 2011, 2012, 2014; Jucker and 
Taavitsainen, 2014) or related disciplines such as historical sociolinguistics (Nevalainen and Raumoline-Brunberg, 2003). ${ }^{1}$ Given the centrality of context ${ }^{2}$ within (historical) pragmatics, I focus, in particular, on what the authors have had to say about the concept; how these individual discussions, when viewed together, signpost an evolution in our (disciplinary) understanding of context, and what appears to be shaping these new/changing views. More specifically, I highlight:

- How the discipline allows for explorations of an array of contexts in addition to the historical - cognitive, cultural, ideological, linguistic/discursive, political, social - dependent on academic positioning.

- That the methods employed, within historical pragmatics, ensure that we can engage in not only form-to-function and function-to-form type studies, but also context-to-form and context-to-function type studies. Compare, for example: (1) an assessment of the possible functions of a particular interrogative form like can you (such as questioning and requesting), (2) an assessment of the possible forms that serve the requesting function in a particular language (such as Open the window, Can you open the window, It's hot in here, etc., in English), and (3) the "tracing" of "how historical contexts, including the co-text, the genre, social situation and/or the culture, shape the functions and forms of language taking place within them" (Archer and Culpeper, 2011: 110). By way of illustration, a researcher might seek to demonstrate how/the extent to which the questioning function, and its various realisations, in times past, was dependent on - and hence shaped by - the language used, contextual factors such as the role and goal(s) of both the questioner and the recipient, the activity type in which they were engaged (dialogue, courtroom interaction, witness deposition, etiquette manual, etc.), and the period in question.

- That we might undertake such methods qualitatively, quantitatively (using corpus linguistic techniques), or using a combination of both.

- That the dataset itself can be an important determining factor in shaping, e.g., social categories used within sociolinguistic/pragmatic annotation schemes -

\footnotetext{
${ }^{1}$ Word-limit constraints prevent the inclusion of additional representative papers of the historical pragmatic- and historical sociolinguistic disciplines.

${ }^{2}$ Context is a crucial concept in pragmatics, of course, such that it is often understood to be the study of what people mean in context, and, hence, the way in which different contexts (cognitive, physical/situational, linguistic/discursive, social, cultural, political, ideological, etc.) contribute to meaning. For a useful overview, see Chapter 1 of Archer and Grundy (2011).
} 
and, in turn, our interrogation of that dataset (Archer and Culpeper, 2003; Nevalainen and Raumolin-Brunberg, 2003).

- That academic positioning - as captured by terms such as sociopragmatics, pragmalinguistics, sociophilology, component view and perspective view (all of which are delineated in this paper) - can sometimes hide the fact that historical pragmatic studies are increasingly demonstrating sociopragmatic, pragmalinguistic and/or sociophilological influences (Nevala, 2011; Archer and Culpeper, 2011), or component and perspective influences (Traugott, 2011).

- That, hitherto, we appear to have neglected some contexts within historical pragmatics - such as how we might "get inside people's heads" to determine motivations and perceptions (Archer, 2011). This particular aspect picks up on the debate as to whether it is possible to tap into the linguistic intuitions of speakers of times past, by using "the availability of ethnographic context and of an optimally complete behaviour record" (Grimshaw, 1990: 281). It necessitates, in turn, that we also consider how optimally complete a behaviour record needs to be to prove useful (Archer, 2013).

\section{Pragmatic Developments in the History of English}

Jucker's (1995) edited collection is a useful starting point, for my purposes, in spite of the absence of context (as a heading) in the subject index. Indeed, the concept of an interdisciplinary context is evident as early as the book's sub-title: with Pragmatic Developments in the History of English immediately pointing to (by presupposing) the efforts made "to make pragmatic linguistics more historical" (Archer, 2005: 6) via the bringing together of the disciplines of pragmatics and historical linguistics. Jacobs and Jucker also focussed on the interdisciplinary context, in their introductory chapter: they explained historical pragmatics as equating to the study of how people made use of their language(s), in both times past and also across time. But they were careful to emphasize how such usage - to be understood appropriately - needed to give just consideration to the given social, cultural and historical contexts in which the interactions took place. They made note of the pragmaphilological approach, for example, which "describes the contextual aspects of historical texts, including the addressers and addressees, their social and personal relationship, the physical and social setting of text production and text reception, and the goal(s) of the text" (ibid: 11). I pick up on this approach in Section 3.2. They also referenced - as a means of distinguishing between - Leech's (1983: 
10-11) general pragmatics, socio-pragmatics and pragmalinguistics - that is, a focus on the general conditions of language use, a focus on the local conditions of language use and a focus on the particular linguistic resources of a given language respectively. General pragmatics was not discussed further in Jacobs and Jucker, and is not developed in this paper. Sociopragmatics and pragmalinguistics are delineated, however (see, in particular, Sections 2.1-3.1).

\subsection{Sociopragmatic/pragmalinguistic distinction within cross-cultural pragmatics}

The sociopragmatic/pragmalinguistic distinction is regularly associated with Leech within historical pragmatic circles - thanks, in part, to Jacobs and Jucker's (1995: 10) reference to his 1983 publication. However, it was first made by (Leech's then PhD student) Thomas (1981, 1983), in order to explain the different levels at which pragmatic failure might occur in a cross-cultural context (Leech, 1983: 18, footnote 13; Culpeper, 2010: 72). I have opted to note this here for two reasons. First, Jacobs and Jucker (1995) rightly emphasised that it was contrastive studies, relating to different languages, which led the way to studies of language use at different periods in the history of the same language. Second, there is an acceptance, within the crosscultural pragmatics field, that an interlocutor's pragmatic knowledge must be both pragmalinguistic and sociopragmatic in orientation (regardless of language). Consequently, pragmalinguistics and socipragmatics are seen as complementary (rather than distinct fields). Consider pragmatic competence. Pragma-linguistically speaking, pragmatic competence means having at our disposal, first, social and culturally-recognised strategies for realizing communicative intentions - such as conventional indirectness - and, second, the linguistic tokens necessary to implement these strategies in our communications, in ways that will be understood by our interlocutors (Roever, 2004: 284). For example, a speaker might opt to perform a conventional indirect request in English, today, by using the can you form. Pragmatic competence, sociopragmatically speaking, requires our having knowledge of social norms, that is, knowing "what ... you do, when, and to whom" in a given context of utterance (Fraser et al., 1981). For example, having some knowledge of mutual rights and obligations, as well as any taboo behaviour to avoid (Thomas, 1983), and - if we are thinking about requests, as before - the potential effect of contextual and/or interpersonal variables such as power differentials, social distance, and degree of imposition (Brown and Levinson, 1987). This helps to explain why people tend to find requesting the time or the salt, using the can you or similar form, less daunting than asking their line manager, Can you sort out a raise 
for me? Even so, there are times when Can you tell me the time? would be deemed inappropriate (and potentially rude): for example, when uttered by a student to a lecturer 10 minutes into a 50-minute workshop. When we talk about pragmatic competence, then, we mean the ability to map pragmalinguistic and sociopragmatic knowledge onto each other, and be able to use that knowledge appropriately under the constraints of a given communicative situation or context.

\subsection{Sociopragmatic/pragmalinguistic distinction within historical pragmatics}

In their introductory chapter, Jacobs and Jucker (1995: 10-11) went on to suggest that general pragmatics, as a framework, would not lend itself as easily to historical pragmatics, as the sociopragmatic and pragmalinguistic frameworks would do. In hindsight, their suggestion that researchers will therefore tend to adopt the latter approaches, when undertaking their historical pragmatic studies, seemed itself to trigger investigations that were typically sociopragmatic or studies that were typically pragmalinguistic. Typical sociopragmatic studies within the field, for example, became ones which traced how a particular speech act function such as apologizing or insulting, or another interactional phenomena relating to $\mathrm{im} /$ politeness, had changed the form (or forms) it employed (see, e.g., Jucker and Taavitsainen, 2000) - all the while emphasizing the need to study such examples of local language use from a specific time in the past in a way that took account of the social and cultural contexts influencing the interaction (Archer, 2005: 7). This explains the strong association between the sociopragmatic approach and "the more Continental European conceptualization of pragmatics as the study of the use of language in its wider social and cultural context" (Jucker and Taavitsainen, 2014: 7). Typical pragmalinguistic studies within historical pragmatics, in contrast, became ones which traced how a particular form had undergone functional change (usually over time). Particularly popular studies, in this respect, are those which trace the grammaticalisation / pragmaticalisation / subjectification of a particular linguistic form or language-internal feature (see, e.g., Traugott and Dasher, 2005) in other words, they share the Anglo-American (micro) focus on "pragmatic motivations for language change" (Jucker and Taavitsainen, 2014: 8).

\section{Sociopragmatic investigations with pragmalinguistic interests}

Although the sociopragmatic versus pragmalinguistic orientation is very much evident in historical pragmatics, even today, there are studies which demonstrate 
both a sociopragmatic and pragmalinguistic influence. In fact, two such representative studies - Nevala (2011) and Archer and Culpeper (2011) - were published in an edited collection explicitly devoted to Historical Sociopragmatics (Culpeper, ed.).

\subsection{Person reference in Late Modern English}

Nevala (2011) investigates how pronouns and nominal terms such as friend were used to refer to third parties in Late Modern English letters and journals - including those penned by Agnes Porter, an eighteenth-century governess whose own pragmalinguistic patterns indicated (interesting contextual shifts in) interpersonal familiarity/distance. For example, when referring to children that she loved as though they were "her own" (2011: 68), she would tend to use endearment terms such as darlings, dear creatures, little cherubs and pretty elves. When addressing her own friends or friends of friends, in contrast, she would tend to adopt one of two patterns (or a combination of both): my X friend, where friend might be pre-modified by adjectives such as old, new and good; and/or honorific title (such as Miss or Mrs) plus first name or surname. Hence, we find examples in her writing such as Miss Jane my old friend and My good friend Mrs Pinnock. Other writers in Nevala's dataset used terms which allowed them to strategically alternate between social positionings: and, as Marmaridou (2011: 98) has observed, they seemed to do so in ways that took note of any "prevalent social and societal constraints" - thereby ensuring the sociopragmatic focus of Nevala's paper. As well as using friend to indicate friendship and intimacy, for example, writers also used it "as a social "softener", as "a booster of the recipient's authority", "as a device to affirm the addressee of the writer's loyalty" and, later in the eighteenth century (in line with the emergence of the middle class), as a strategic means of raising their profile. By way of illustration, some writers promoted themselves as "an intimate friend" of "people with societal prestige in order to appear more socially influential" themselves (Nevala, 2011: 74-5).

\subsection{The sociophilological approach}

A second investigation within the same edited collection - by Archer and Culpeper (2011) - introduced a new approach into historical pragmatics: that of sociophilology. As the authors explain, this approach shares some similarities with pragmaphilology, in the sense of seeking to describe not only linguistic form and pragmatic function but also "the contextual aspects of historical texts, including the 
addressers and addressees, their social and personal relationship, the physical and social setting of text production and text reception, and the goals of the text" (Jacobs and Jucker, 1995: 11). Indeed, the sociophilogical approach involves "describing or tracing how historical contexts, including the co-text, the genre, social situation and/or the culture, shape the functions and forms of language taking place within them" (Archer and Culpeper, 2011: 110). There are some important differences between the two, however, not least that the sociophilological approach is not limited to synchronic concerns, as pragmaphilology appears to be, and can proceed from context to form or context to function (something that was not made clear, when Jacobs and Jucker described pragmaphilology). In addition, the socio- part of the label, sociophilology, ensures that, much like sociopragmatics, sociophilology has a fundamental interest in the "local' conditions of language use" (cf. Leech, 1983: 10).

Archer and Culpeper go on to argue that it is their methodological point of departure - of using a combination of corpus-linguistic (CL) techniques (specifically pragmatic annotation, as exemplified by the Sociopragmatic Corpus (1640-1760), in conjunction with keyness analysis) ${ }^{3}$ - which makes a focus on diachronic as well as synchronic concerns possible.

\subsubsection{Pragmatic annotation (within the Sociopragmatic Corpus)}

The Sociopragmatic Corpus is a 120-year subset of the Corpus of Early English Dialogues (1560-1760), and consists of trial texts and drama texts which have been manually annotated for sociopragmatic phenomena (i.e., each participant's role in the interaction, as well as their status, sex and age (where known)). The sociopragmatic scheme used was devised by Archer and Culpeper (2003), and includes speaker information and addressee information at the utterance level. The authors argue that this was the best way of capturing the dynamism of the speech within their dataset (cf. corpora which include sociolinguistic information in the header of a text). They also wanted the results of their electronic searches to provide (on-screen) sociopragmatic information relating to the participants themselves (i.e., their status, sex, age and role), at the same time as providing a sense of what the participants said (or, in the case of the trial texts, were reported as saying).

Suffice it to say, researchers can easily make use of categories such as status, sex, age and role to identify, retrieve and analyse the interaction sequences of

${ }^{3}$ The use of CL methodologies within historical pragmatics is yet another example of how historical pragmaticians regularly work across linguistic disciplines (see Section 2.3). 
particular dyads, using computational software/CL techniques. For example, Archer and Culpeper (2011) used Wmatrix (a web-based software tool for corpus analysis and comparison $^{4}$ ) to undertake key part-of-speech investigations, key word investigations and key semantic field investigations in respect two sets of dyads from the Sociopragmatics Corpus:

(1) Male examiners conversing with (male/female) examinees.

(2) Masters or mistresses conversing with (male/female) servants.

The keyness approach involves automatically creating and then comparing two lists (be they words, part-of-speech categories or semantic domains) as a means of discovering the most statistically-significant items within the first list when compared with the second list, where the first list constitutes the particular dataset of interest, and the second list, a comparative corpus. Archer and Culpeper were seeking to identify the statistically-based style markers of examiners, examinees, masters, mistresses and servants, that is, those linguistic features which appear to characterise these specific groups. They thus paid particular attention to each group's use of personal pronouns, interjections, imperative verbs, politeness formulae, etc. For example, they noticed that male and female examinees overused the first person, statistically speaking. But they also showed some interesting differences. For female examinees mainly used $I$ as part of narrative reports, in line with their role as witnesses. Hence, we get example utterances such as I never saw them together and I went to see the prisoner at Newgate. ${ }^{5}$ Many of the male examinees in the Sociopragmatic Corpus were defendants, however: which helps to explain why, in their interactions, there are instances of $I$ being used in conjunction with hedging devices, modality, equivocation strategies, etc. Hence, we get examples such as the following, when a male examinee flouted the maxim of Quantity (Grice, 1975) as a means of emphasising what he did not do/say to others: I can not answer directly, I do not say if he was acquainted with me, but I say this, that he did declare he did not know me. ${ }^{6}$

\footnotetext{
${ }^{4}$ See http://ucrel.lancs.ac.uk/wmatrix/ for details.

${ }^{5}$ A female examiner by the name of Jane Finch also regularly used the idiosyncratic pattern, said I instead of I said.

${ }^{6}$ Arguably, the opening, I can not answer directly, also flouts the Manner maxim: for, although it has the appearance of an opt-out, it was a means of achieving a level of hedging, in context.
} 


\subsubsection{The contextual shaping effect(s) of the datasets used}

Archer and Culpeper (2003) emphasise that they spent extensive periods digging into primary sources - i.e., each text within the Sociopragmatic Corpus - in order to work out what the variables should be for each of the fields they use (Role, Status, Sex, Age). They also dug into secondary sources as a means of retrieving relevant information in respect to, for example, the ages of famous participants (involved in some of the trials); typical life spans within this 120-year period; and contemporary understandings of the status system at this time. Their status variables, in particular, required a detailed knowledge of the period as well as the work of nearcontemporaries such as King - who published the 1695 criteria relating to 'Ranks, Degrees, Titles and Qualifications' - and Harrison - who published the 1577 criteria relating to 'titular nobility, knights, esquires'.

Terttu Nevalainen and Helena Raumolin-Brunberg have been particularly influential when it comes to the study of (similar) sociolinguistic phenomena in an historical context. Nevalainen and Raumolin-Brunberg (2003) were involved in the development of the Corpus of Early English Correspondence (1400-1800) and, more importantly, given the focus of this section, in the development of models via which to capture the (organisation of) social networks in the early Modern English period. They ultimately decided on a model based on four groupings: the Upper Ranks, Social Aspirers, Middle Ranks and Lower Ranks. I compare these groupings with the status categories used by Archer and Culpeper (2003), in Figure 1 (below). I do so to show that how we see the world (as researchers) is not only influenced by well-known socio-historical categories such as gentry - or even contemporary perceptions of the world that we have researched - but also the type of data we are working with when we begin to develop our categorisation schemes:

N\&R's (2003) status categories

Upper Ranks

Social Aspirers

Middle Ranks

Lower Ranks
A\&C's (2003) status categories

Nobility
Gentry
Professions
Other Middling Groups
Ordinary Commoners
Lowest Groups

Gentry

Other Middling Groups

rdinary Commoners

Lowest Groups

Figure 1: Comparison of status categories 
By way of illustration, Nevalainen, Raumolin-Brunberg and their team of researchers were working with correspondence data. As the middle and upper groupings of society were more likely to be (fully) literate, during their period of interest, they originally took a lot of care when teasing out these particular categories - before ultimately deciding on a model that, although far less nuanced, allowed for more general patterns of language usage to be identified (cf. Rissanen, 1989). In contrast, Archer and Culpeper (2003) were working with speech-related texts taken from trials and comedy plays representative of the later Early Modern English period. These datasets were found to contain too many groups to subsume under the general term Lower Ranks as Nevalainen and Raumolin-Brunberg had done. Archer and Culpeper therefore decided to include separate categories for (as a means of distinguishing between) Ordinary Commoners and the Lowest Groups. Like Nevalainen and Raumolin-Brunberg, they opted for (two) broad categories as opposed to more specific categories (common seamen/soldiers, servants, paupers, the unemployed, vagrants, etc.) as a means of avoiding the Mystery of Vanishing Reliability $^{7}$ (Rissanen, 1989).

\section{Recontextualising decontextualised results}

For (historical) pragmaticians, how a particular form is functioning - in a given text or interaction - cannot be truly understood without also considering the particular context of utterance. This might be in respect to:

- Time, place, cultural schemas - and, arguably, worldviews - in operation, etc.

- What happens immediately before and immediately afterwards.

- Who is interacting with whom, and for what purpose(s).

Yet, when we use corpus linguistic techniques to detect (historical) pragmatic phenomena, we are effectively breaking down texts such that words, phrases, etc., become de-contextualised. By way of illustration, I have sought to locate an "aggression space", historically, using the previously mentioned Wmatrix tool, based on a corpus of 200 historical courtroom trial extracts (Archer, 2014). Wmatrix was the tool of choice because

\footnotetext{
${ }^{7}$ The Mystery of Vanishing Reliability dictates that annotation schemes which are too detailed will tend to tell us very little about the more general patterns of language usage (Rissanen, 1989).
} 
the 232 SEMTAGs underpinning Wmatrix are premised on the notion of a semantic field, and Jucker and Taavitsainen's (2000) pragmatic space is meant to be analogous to a semantic field (albeit one which depends on several contextual factors - i.e., formal, creative, ad hoc, conventional, particular, speaker attitude, etc.);

(ii) Jucker and Taavitsainen (2000) have used this notion of a pragmatic space to trace phenomena that overlap with the notion of an "aggression space": they traced the development of insults over time, based on the above-mentioned contextual factors.

Archer (2014) is included in an edited collection, which introduces Diachronic Corpus Pragmatics (Taavitsainen et al, eds.): a field of research that combines historical linguistics, corpus linguistics and pragmatics. As Jucker and Taavitsainen (2014: 3, 11) explain, although these academic disciplines have been perceived as being "more or less incompatible" in the past, their recent coming together marks a thrust in historical pragmatics towards investigations which share similarities with the older "philological view of textual scholarship", albeit in a new "form...refreshed by new tools and innovative combinations of methodologies backed up by statistics". In their introduction to this edited collection, Jucker and Taavitsainen also explain how corpus linguistics and pragmatics, in particular, share an interest in variability - but that, within the latter discipline, variability is often "a more dynamic notion" (2014: 8), in practice. As Jucker and Taavitsainen state, pragmatic variability is inter-related with negotiability (a second core concept of pragmatics) - not least because of "the range of possibilities from which choices can be made at any given moment in the course of interaction". This leads Jucker and Taavitsainen to suggest, in turn, that each utterance in an interaction can effectively create "a new context" (2014: 8): hence the importance of recontextualising any decontextualised tool-generated results, where pragmatic meaning is our focus. Consider my three-step approach for automatically identifying potential evidence of verbal aggression in the Old Bailey trials (Archer, 2014). As a first step, I focused on the words and phrases captured within six pre-chosen SEMTAG categories of the Wmatrix system ${ }^{8}$ (Speech Acts, Im/Politeness, (Lack of) Respect, Evaluation: Good/Bad, Evaluation: True/False and Anger). As a second step, I scrutinised the results gleaned via the expand context component within the tool - and, where

${ }^{8}$ The Wmatrix system is designed to be able to identify words/phrases associated with - so that they might be automatically assigned to -137 part-of-speech tags as well as the aforementioned predefined SEMTAGs. 
possible, the original documents themselves - as a means of discarding any "false leads". As a third step, I ensured that any (semantic) meanings assigned by Wmatrix were sensitive to the period they represent in addition to being relevant in context. I found, for example, that although Wmatrix automatically assigned all instances of politely to the politeness semtag, $\mathrm{S} 1.2 .4+$, it was used in one context in a question that sought to suggest 'the covert nature of the art of pick-pocketing' (Archer, 2014: 288): Did not you hear the foreigner say no force was used, but that his watch was taken most dexterously and politely? (Trial of John Wheeler, 18 April 1787 [t1780418-96]).

The need for historical sensitivity to meaning-in-context has recently been addressed more comprehensively via the Semantic Annotation and Mark Up for Enhancing Lexical Searches (SAMUELS) project (amongst others). ${ }^{9}$ As part of SAMUELS, the 232 semantic categories within Wmatrix have been mapped to 4,033 themed categories derived from the Historical Thesaurus of the Oxford English Dictionary (Kay et al., 2009). This means that researchers can now (better) discover, quantitatively speaking, which words/phrases were used to perform a particular pragmatic or discursive function (such as discourtesy and verbal aggression) throughout the ages (see, e.g., Wattam et al, 2014; Archer and Malory, 2017). The historically-sensitive tool should still be viewed as an investigative aid only, nonetheless - especially when exploring pragmatic phenomena from an historical period or in historical texts (such as courtroom records) where the concept of meaning included (and arguably encouraged) alternative interpretations.

\section{A coming together of the component and perspective views}

In Section 2.2, I touched on the Anglo-American approach, and its associations with pragmalinguistics, and the Continental-European approach, and its associations with sociopragmatics Yet, we might equally link Anglo-American scholars to the component view of historical pragmatics, and Continental-European scholars to the perspective view of historical pragmatics, where the former focuses on languageinternal features and the latter, on both language-internal and language-external factors (Taavitsainen and Jucker, 2010: 5) - but as a means of understanding "patterns of intentional human interaction", at a specific period in time or across time periods, "as determined by the condition of society", "the historical

\footnotetext{
${ }^{9}$ The SAMUELS project was funded by the Arts and Humanities Research Council in conjunction with the Economic and Social Research Council (grant reference AH/L010062/1).
} 
developments of these patterns, and the general principles underlying such developments" (Jucker 2008: 895). For example, in my own work, I have adopted what might be regarded as a perspective view to investigate how a particular linguistic activity - such as the cross-examination of a witness - both shaped and was shaped by the role assigned to each participant, their allowable contributions, the historical period in question, etc. (Archer 2005: 7; Archer 2012). In Archer (2012), for example, I reveal how the aforementioned lawyer, William Garrow, operated in a judicial system that - for much of his career - prevented him (and his fellow defence lawyers) from giving opening statements or making closing arguments on behalf of clients. As such, the only opportunity he and other late eighteenth-century defence counsels had to signal (albeit indirect) messages to jurors was during the (cross-)examination phases of a trial - when, that is, the Court allowed them to speak. Garrow is well known, amongst historians, for having developed questioning techniques that afforded him the opportunity of not only gleaning information from unfriendly witnesses, which might help his own client's case, but also commenting on the apparent (in)adequacy, (non-)clarity, (ir)relevance or (non-)truthfulness of their responses. In one trial, for example, he linked the victim-prosecutor (William Grove, the elder) to illicit activities - via, first, the mention of moonlight men and smugglers and, second, via suggesting that Grove was friendly with such men. He also framed Grove as a perpetual drunkard via his yes-no question, Was you as drunk that night as you are now, how much have you been drinking to-day? When the victim-prosecutor insisted he had "drank no gin", Garrow persisted with his drunkard frame in ways that suggested Grove was lying ("What other spirits?").

Elizabeth Close Traugott is perhaps the most well-known Anglo-American scholar whose studies typically adopt a component view. She is particularly known for paying specific attention to 'the discourse contexts in which [semantic] changes occur' - that is the immediate co-text - as a means of explaining the role that implied meaning and pragmatic inferencing played in bringing about changes in meaning which - over time - became grammaticalized $(2004: 539,560)$. The reason a close investigation of the immediate co-text is so important to researchers adopting a component view of pragmatics is immediately evident in Traugott's (2012) be going to investigation. Traugott was interested in determining whether there was any evidence of the phrasal verb being used in pragmatically ambivalent ways once the grammaticalization process - of motion verb to future marker - had taken place. She found that its pragmatic ambiguity was very much dependent on or related to its cooccurrence with terms such as carry, do, buy, visit, etc. In fact, she highlights 
twenty-six pragmatically ambiguous tokens within her two datasets (the Helsinki Corpus and Old Bailey records) which, in turn, represent 18 specific types (dependent on the above collocates).

The above study is not Traugott's only study of trial data. In fact, she has investigated how trial reporters used (in)direct addresses in order to "construct and engage with their audiences" (Traugott 2011: 69). This particular study, however, is more typical of the perspective view of pragmatics - because of a focus on languageinternal features (i.e., address terms like Reader and the public) and languageexternal factors (i.e., the hegemonic ideologies underpinning such terms and, hence, shaping reader perceptions). For example, Traugott's discussion of the following extract from a 1674 trial makes mention of an ideology which sought to safeguard the social order by encouraging contemporaries to converse about unruly passions in ways that ultimately regulated them (see also Brewer 1997: 102):

READER, Wherein canst thou more experience thy self for the ordering of a good Conversation, than by seeing the follies of those, who either by their own idle or extravagant living are forced to seek out those ways and means, which either are destructive in themselves, or purchase shame and destruction in their end? (29 April 1674, f16740429-1).

\section{Mental aspects of pragmatic theory}

Traugott's (2011) emerging interest in reporters' attempts to influence the perceptions of their readers is particularly interesting when viewed in light of an earlier comment that she has made in respect to modern researchers not being able to "tap linguistic intuitions of speakers several hundred years ago" and thus having to "look to competence for use" (Schwenter and Traugott, 1995: 244). The problem of "get[ting] into people's heads" is not peculiar to historical studies, of course. Rather, it is an issue for any linguist and also for any interlocutors engaging in talk: hence the general acceptance that the "availability of ethnographic context and of an optimally complete behaviour record permits analysts to make such inferences and attributions which are 'for-the-most-practical-purposes' [...] no less plausible than those of actual participants" (Grimshaw, 1990: 281). 
The cognitive context nonetheless remains somewhat under-researched within historical pragmatics (and, potentially, for historical linguistics more generally). ${ }^{10}$

\subsection{Clashing reality paradigms and representational frames}

My curiosity in respect to what might be gained were we to seek to systematically explore ways of understanding the cognitive/psychological traits of others, as part of our historical analyses, has led to my developing an interest in interlocutors' reality paradigms and representational frames, as evidenced in their interactions (Archer, 2002, 2011). From my perspective, a reality paradigm equates to "the systems of beliefs [and] values ... by reference to which a person or a society comprehends the world" (Fowler 1986: 130), that is, their truth filter. Representational frames, in contrast, relate to the way(s) in which interlocutors opt to "represent the character traits, ideas and opinions of and even statements made by others" (Locher and Watts 2008: 99, n9). Consider the case of Edward Coleman, who was tried for Treason in November 1678. When being questioned, Coleman felt the need to highlight a "dreadful" truth, from his perspective - "the violent prejudices that seem[ed] to be against every man in England that confess'd to be a Roman Catholick" (Trial of Edward Coleman, Corpus of English Dialogues) adding that although a Roman Catholic might be "innocent", he would nonetheless be found guilty. That is to say, the reality paradigm of the country at large was such that they could not discern the truth before them. Note, then, that Coleman's turn equated to an indirect means of not only establishing his innocence, but of also highlighting a ROMAN-CATHOLIC-EQUALLED-TRAITOR reality paradigm that he believed to be prevalent at that time, and which he believed required a form of "positive discrimination" from the judges to subvert. In his response, Judge William Scroggs initially reassured Coleman that he would receive a "fair, just, and legal Trial",

You need not make any preparations for us in this matter, you shall have a fair, just, and legal Trial; if Condemned, it will be apparent you ought to be so; and without a fair Proof, there shall be no Condemnation.

But he went on to assert:

\footnotetext{
${ }^{10} \mathrm{My}$ thanks to a reviewer for highlighting that the cognitive context remains largely underresearched within historical linguistics.
} 
Therefore you shall find, we will not do to you, as you do to us, blow up at adventure, kill people because they are not of your perswasion; our Religion teacheth us another Doctrine, and you shall find it clearly to your advantage. We seek no mans blood, but our own safety. But you are brought here from the necessity of things, which your selves have made; and from your own actions you shall be condemned, or acquitted.

The implications of this statement seem to confirm that Coleman was right to fear that justice would be coloured by a ROMAN-CATHOLIC-EQUALLED-TRAITOR reality paradigm on the part of the judges. For the opposition between we and you effectively positioned Coleman with those Catholics who blew up at adventure, kill[ed] people, etc., and Scroggs, with those whose Religion taught what, for him at least, was a more tolerant Doctrine. Notice, too, the guilt implicature within his claim that Coleman had been brought before the Court because of his own actions (i.e., a necessity... which he had made) and the ordering of condemned and acquitted when stating the possible consequences of those actions.

The interaction between Coleman and Scroggs also provides us with interesting clues as to the identities being constructed for Coleman. According to Scroggs, and many of those listening on, he was a criminal; yet, Coleman tried hard to imply that he was, in fact, an "innocent but persecuted man". Indeed, in Coleman's very next turn, he flouted the Quantity maxim to emphasise that he was telling the truth.

Pris. $\quad$... I promised I would confess all I knew. And ... what I said in Prison is true, and am ready at any time to Swear and Evidence, that that is all the truth ...

L.C.J. It is all true that you say: but did you tell all that vvas true?

Pris. I know no more, than what I declared to the Two Houses.

L.C.J. [...] Do you believe, there vvas no Negotiation after 75 . because vve have not found them [=letters]? Have you spoke one wword to that? Have you confessed, or produced those Papers and Weekly intelligence? When you ansvver that, you may have credit; vvithout that, it is impossible: For I cannot give credit to one vvord you say, unless you give an account of the subsequent Negotiation.

However, judges' "guilty" paradigms could be so strong, in times past, that they could not - or would not - interpret implicatures as defendants and, on occasion, 
witnesses intended them to be interpreted (Archer, 2002). In fact, in this particular case, the judge's response - "it is all true that you say: but did you tell all that vvas true?" - intimated that Coleman was being economical with the truth. Once again, Coleman sought to imply that he had told everything he knew, but the Lord Chief Justice remained unconvinced. In fact, his turn demonstrates his strong belief that there had been negotiations with the French after 1675 - and - until Coleman produced evidence - which, if we're to believe Coleman's version of events, did not in fact exist - then the judge explicitly signalled that he could not "give credit to one vvord" of Coleman's evidence. To the judge's credit, he did address Oates - the man who had implicated Coleman - to make sure that Coleman was "condemned by plain Evidence of Fact" --- in order "that Mr Coleman may be satisfied in the Trial". But - even in this turn - the judge's reality paradigm played a part

Mr Oates, we leave it to your self to take your own way, and your own method; only this we say, here's a Gentleman stands at the Bar for his life; And on the other side, the King is concerned for His life; you are to speak the truth and the whole truth; for there is no reason in the world that you should adde any one thing that is false ... you have taken an Oath, and you being a Minister, know the great regard you ought to have of the sacredness of an Oath; and that to take a man's life away by a false Oath is murther, I need not teach you that. But that Mr.

Coleman may be satisified in the Trial, and all people else by satisfied, there is nothing required or expected, than downright plain truth, and without any arts to conceal, or expatiate, or to make things larger then $[$ sic $]$ in truth they are; he must be condemned by plain Evidence of Fact.

Notice, in particular, Scrogg's comment regarding Oates's occupation, which suggests the judge's mindset was such that he believed being a (protestant) "Minister" equated to being truthful. A longer exploration of Coleman's trial would allow us to see that Coleman was the victim of a philosophical strategy that is still evident in today's adversarial courtrooms: that, if someone is put under enough pressure, they will tell the truth, or the truth will emerge despite the teller (Lakoff 1990) - even when that particular version of the "truth" does not, in fact, exist. Ironically, if Scroggs had have pushed Oates more, when questioning him, instead of "leaving it to [him] to take [his] own way", he may have learned that Oates had been a member of a Jesuit house in France, until he was expelled; and had also been accused of perjury and put in prison (but managed to escape). 


\subsection{Framing Others}

The late nineteenth-century defamatory libel trial brought by Oscar Wilde reveals how reality paradigms and representational frames were sometimes used/manipulated, in the context of the historical courtroom, in order to frame someone as deviant. Wilde took the Marquis of Queensberry to trial in 1895, because the latter had intimated that Wilde was a homosexual. At that time in England, homosexuality was deemed to be both a moral and legal crime. Wilde held a different view, however: and Carson (the lawyer for Queensberry) used these differences in worldviews to suggest that Wilde was not only deviant but extremely dangerous to Victorian society. ${ }^{11}$ By way of illustration, when Carson sought to determine whether Wilde thought one person could adversely affect another, Wilde initially asserted that, as far as he was concerned, there was no "influence, good or bad, from one person over another". At which point, Carson asked

C: A man never corrupts a youth?

W: I think not.

C: $\quad$ Nothing he could do would corrupt him.

$\mathrm{W}$ : Oh, if you are talking of separate ages it is nonsense.

C: $\quad$ No sir, I am talking common sense.

W: Do not talk like that ... personally, as a mere philosophical point, I don't think - I am talking of grown human beings - that one person influences another. I don't think so. I don't believe it.

C: You don't think that one man could exercise any influence over another? I may take that as a general statement?

W: As a general statement, yes. I think influence is not a power that can be exercised at will by one person over another: I think it is quite impossible psychologically.

C: You don't think that flattering a young man, telling him of his beauty, making love to him in fact, would be likely to corrupt him?

W: No.

(Cross-examination of Wilde, Wednesday pm 3rd April 1895 [Holland 2004.: 102])

\footnotetext{
${ }^{11}$ Being able to convince a jury that Wilde's behaviour could adversely affect Victorian society was important as it helped to confirm that Queensberry's actions were "for the public benefit"; something which had to be proven legally for Queensberry to be found not guilty of libel.
} 
Notice, in particular, Carson's use of repetition, here, as well as his assertion that he was not talking "nonsense", as Wilde suggested, but rather "talking common sense". Wilde did not seem to notice the danger in continuing this discussion from a philosophical or psychological standpoint. But it was dangerous - as it allowed Carson to re-frame "a general statement" about someone's ability to influence another into a question that specifically allowed Carson to mention activities - such as "flattering a young man, telling him of his beauty, making love to him" - which, as far as Victorian England were concerned, were the kinds of activities that were "corrupt[ing their] youth". Hence, by answering "No" to this question, Wilde showed himself to have a reality paradigm that very much clashed with the country's world view.

\section{Conclusion}

Historical pragmaticians use context as an overarching term which actually brings together - and thus has the potential to allude to - an array of contexts in addition to the historical: be it cognitive, cultural, social, (Verschueren 1999: 7, 109) ideological and/or political. Some of the latter (historical, ideological, political) point, in themselves, to multiple contexts (consider a diachronic study, for example, or an investigation of a political text-type such as pamphlets, which often necessitates an understanding of clashing political and ideological views). In this paper, I began by discussing a sixth context: that of the academic/disciplinary context. In particular, I explored how the academic/disciplinary context can (pre-) determine the theories and/or methodologies researchers draw upon when making sense of their datasets (Sections 2.1-5). However, I have also suggested that some of the labels used to explain academic or disciplinary positioning are best seen today as highlighting a primary (rather than the only) focus within a particular sub-field. For many studies, within historical pragmatics, combine the sociopragmatic and pragmalinguistic perspectives (Sections 3-3.2) or the component and perspective views (Section 5). This begs the question as to whether these terms are still needed - and explains my use of parentheses around "socio" in the title of this paper.

Some of the newer approaches to emerge over the past 20 years - in particular, sociophilology - have deliberately sought to make context their investigative starting point, rather than language form or interactive function, whilst also advocating the use of corpus linguistic techniques (which, in turn, promotes a focus on quantitative as well as qualitative findings within the field: Section 3.2). This 
often means concentrating on several contexts simultaneously, such that researchers remain sensitive to the shaping potential of the linguistic, socio-cultural, political and historical contexts (i.e., the roles established by the activity type(s)/genres/ communities of practices/organisational practices, and any prevailing ideologies which might have underpinned them, etc.). The increasing use of corpus linguistic techniques has been matched by the development of (historical) pragmatic annotation schemes (Section 3.2.1), the re-development of automatic analysis systems (designed with modern data in mind) so that they handle historical data more sensitively (Section 4) and a (welcome) return to an older "philological view of textual scholarship", albeit in a new "form ... refreshed by new tools and innovative combinations of methodologies backed up by statistics" (Jucker and Taavitsainen, 2014: 3, 11). This said, it is important to understand that the dataset itself can be an important determining factor in shaping, for example, the social categories used within sociolinguistic/pragmatic annotation schemes - and, in turn, researchers' interrogations of that dataset (Section 3.2.2).

I have suggested that, within historical pragmatics in particular, we have been attentive to most of the contexts highlighted above; but that there is more to do when it comes to finding systematic ways of exploring motivations and perceptions (see Sections 6.-6.2). This is perhaps the most controversial context to explore given the difficulties associated with "get[ting] into people's heads" and the current debates in respect to intentionality, within (historical) pragmatics. Following Grimshaw (1990: 281), one way forward is to accept that it is possible to tap into the linguistic intuitions of speakers of times past, by using evidence from the "ethnographic context" as well as an "optimally complete behaviour record" (Grimshaw, 1990: 281) - but only if we give some thought to what constitutes an optimally complete behaviour record within historical pragmatics (Archer, 2013). For, according to Labov (1994: 11), we are forced to make "the best use of bad data", that is, to reconstruct (the meaning of) interactions within a given activity type, genre and/or community of practice - and assess the evolution of such discursive practices over time - using written documents only. This undoubtedly makes psychological/cognitive investigations more difficult. I would advocate, nonetheless, that concepts such as reality paradigms and representational frames appear to make them possible.

\section{References}


A Corpus of English Dialogues 1560-1760. 2006. Compiled under the supervision of Merja Kytö (Uppsala University) and Jonathan Culpeper (Lancaster University).

Archer, Dawn. 2002. “Can innocent people be guilty?”. A sociopragmatic analysis of examination transcripts from the Salem Witchcraft Trials'. Journal of Historical Pragmatics 3(1): 1-30.

Archer, Dawn. 2005. Questions and Answers in the English Courtroom (16401760): A Sociopragmatic Approach. Amsterdam/Philadelphia: John Benjamins.

Archer, Dawn. 2011. 'Libeling Oscar Wilde: The case of Regina vs. John Sholto Douglas'. Journal of Politeness Research 7(1): 73-99.

Archer, Dawn. 2012. 'Assessing Garrow's aggressive questioning style'. In Gabriella Mazzon (ed). English Historical Dialogue Studies, 301-320. Milano: FrancoAngeli.

Archer, Dawn. 2013. 'Historical Pragmatics: Evidence from the Old Bailey'. Transactions of the Philological Society. 1-13.

Archer, Dawn. 2014. 'Exploring verbal aggression in English historical texts using USAS: the possibilities, the problems and potential solutions'. In Irma Taavitsainen, Andreas H. Jucker and Jukka Tuominen (eds) Diachronic Corpus Pragmatics, 277-301. Amsterdam: John Benjamins.

Archer, Dawn and Jonathan Culpeper. 2003. 'Sociopragmatic annotation: New directions and possibilities in historical corpus linguistics'. In Andrew Wilson, Paul Rayson and Tony McEnery (eds) Corpus Linguistics by the Lune: Studies in Honour of Geoffrey Leech, 37-58. Frankfurt: Peter Lang.

Archer, Dawn and Jonathan Culpeper. 2011. 'Identifying key socio-pragmatic usage in plays and trial proceedings (1640-1760): An empirical approach via corpus annotation'. In Jonathan Culpeper (ed) Historical Sociopragmatics, 109-132. Amsterdam/Philadelphia: John Benjamins.

Archer, Dawn and Peter Grundy. 2011. Pragmatics Reader. London: Routledge.

Archer, Dawn and Bethan Malory. 2017. 'Tracing facework strategies over time using semi-automated methods'. International Journal of Corpus Linguistics 22(1): 27-56.

Brewer, John. 1997. "The most polite age and the most vicious". Attitudes towards 
culture as a commodity, 1660-1800'. In Ann Bermingham and John Brewer (eds) The Consumption of Culture 1600-1800, 341-61. London/New York: Routledge.

Brown, Penelope and Steven C. Levinson. 1987. Politeness: Some Universals in Language Usage. Cambridge: Cambridge University Press.

Crystal, David. 1995. The Cambridge Encyclopaedia of the English Language. Cambridge: Cambridge University Press.

Culpeper, Jonathan. 2010. 'Historical Sociopragmatics'. In Andreas H. Jucker and Irma Taavitsainen (eds) Historical Pragmatics, 69-95. Berlin: Walter de Gruyter.

Fowler, Roger. 1986. Linguistic Criticism. Oxford: Oxford University Press.

Fraser, Bruce, Ellen Rintell and Joel Walters. 1981. 'An approach to conducting research on the acquisition of pragmatic competence in a second language'. In Diane L. Larson-Freeman (ed.) Discourse Analysis, 75-81. Newbury House: Rowley Mass.

Grice, H. Paul. 1975. 'Logic and conversation'. In Peter Cole and J. L. Morgan (eds) Syntax and Semantics. Vol 3: Speech Acts, 41-58. London: Academic Press.

Grimshaw, Allen. 1990. 'Research on conflict talk: Antecedents, resources, findings, directions'. In Allen Grimshaw (ed.) Conflict Talk: Sociological Investigations of Arguments in Conversation, 139-59. Cambridge: Cambridge University Press.

Harrison, William. (1577[1965]). 'The Description of England'. In Holinsched's Chronicles: England, Scotland and Ireland, I, England, 221-42. London: AMS Press.

Holland, Merlin. 2004. The Real Trial of Oscar Wilde. HarperCollins.

Jacobs, Andreas and Andreas H. Jucker. 1995. 'The historical perspective in pragmatics'. In Andreas H. Jucker (ed) Historical Pragmatics. Pragmatic Developments in the History of English, 3-36. Amsterdam/Philadelphia: John Benjamins.

Jucker, Andreas H. (ed). 1995. Historical Pragmatics. Pragmatic Developments in the History of English. (Pragmatics \& Beyond Series 35). Amsterdam/Philadelphia: John Benjamins.

Jucker, Andreas H. 2008. 'Historical Pragmatics'. Language and Linguistics Compass 2: 894-906. 
Jucker, Andreas and Irma Taavitsainen. 2000. 'Diachronic speech act analysis: Insults from flyting to flaming'. Journal of Historical Pragmatics 1: 67-95

Jucker, Andreas and Irma Taavitsainen. 2014. 'Diachronic corpus pragmatics: Intersections and interactions'. In Irma Taavitsainen, Andreas H. Jucker, and Jukka Tuominen (eds) Diachronic Corpus Pragmatics, 3-26. Amsterdam: John Benjamins.

Kay, Christian, Jane Roberts, Michael Samuels and Irené Wotherspoon. 2009. Historical Thesaurus of the OED. Oxford: Oxford University Press.

King, Gregory. 1695. 'Ranks, degrees, titles and qualifications'. Reprinted in Thirsk, J. \& Phillips Cooper, J. (eds, 1972). Seventeenth-Century Economic Documents, 751-57. Oxford: Clarendon Press.

Labov William. 1994. Principles of Linguistic Change: Internal Factors. WileyBlackwell.

Lakoff, Robin T. 1990. Talking Power: The Politics of Language. USA: Basic Books.

Leech, Geoffrey. 1983. Principles of Pragmatics. London: Longman.

Locher, Miriam A. and Richard J. Watts. 2008. 'Relational work and impoliteness: Negotiating norms of linguistic behaviour'. In Derek Bousfield and Miriam A. Locher (eds) Impoliteness in Language: Studies on its interplay with power in theory and practice (Language, Power and Social Process 21), 77-99. Berlin \& New York: Mouton de Gruyter.

Marmaridou, Sophia. 2011. 'Pragmalinguistics and Sociopragmatics'. In Wolfram Bublitz and Neal R. Norrick (eds) Foundations of Pragmatics, 77-106. Berlin: Walter de Gruyter.

Nevala, Minna. 2011. 'Altering distance and defining authority: Person reference in Late Modern English'. In Jonathan Culpepepr (eds) Historical Sociopragmatics, 61-82. Amsterdam/Philadelphia: John Benjamins.

Nevalainen, Terttu, and Helena Raumolin-Brunberg. 2003. Historical Sociolinguistics: Language Change in Tudor and Stuart England. London: Longman.

Rissanen, Matti. 1989. 'Three problems associated with the use of diachronic corpora'. ICAME Journal 13: 16-19.

Roever, Carsten. 2004. 'Difficulty and Practicality in Tests of Interlanguage Pragmatics'. In Diana Boxer and Andrew D. Cohen (ed) Studying Speaking to 
Inform Second Language Learning, 283-301. Clevedon: Multilingual Matters. Schwenter, Scott. A. and Elizabeth C. Traugott, 1995. 'The semantic and pragmatic development of substitutive complex prepositions in English'. In Andreas H. Jucker (ed) Historical Pragmatics, 243-73. Amsterdam/Philadelphia: John Benjamins.

Taavitsainen, Irma and Andreas H. Jucker. 2010. 'Trends and developments in historical pragmatics'. In Andreas H. Jucker and Irma Taavitsainen (eds) Historical Pragmatics, 3-30. Berlin/New York: Mouton de Gruyter.

Taavitsainen, Irma, Andreas H. Jucker and Jukka Tuominen. 2014. (eds.) Diachronic Corpus Pragmatics. Amsterdam and Philadelphia: John Benjamins

Thomas, Jenny. 1981. Pragmatic failure. University of Lancaster: Unpublished MA dissertation.

Thomas, Jenny. 1983. 'Cross-cultural pragmatic failure'. Applied Linguistics 4(2): 91-112.

Traugott, Elizabeth C. 2004. 'Historical Pragmatics'. In Laurence R. Horn and Gregory Ward (eds.) The Handbook of Pragmatics, 538-61. Oxford: Blackwell.

Traugott, Elizabeth C. 2011. 'Constructing the audiences of the Old Bailey Trials 1674-1834'. In Päivi Pahta and Andreas H. Jucker (eds) Communicating Early English Manuscripts, 69-80. Cambridge: Cambridge University Press.

Traugott, Elizabeth C. 2012. 'On the persistence of ambiguous linguistic contexts over time: implications for corpus research on micro-changes'. In Joybrato Mukherjee and Magnus Huber (eds) Corpus Linguistics and Variation in English: Theory and Description, 231-46. Amsterdam: Rodopi

Traugott, Elizabeth C. and Richard B. Dasher. 2005. Regularity in Semantic Change. Cambridge: Cambridge University Press.

Verschueren, Jef. 1999. Understanding Pragmatics, London: Arnold.

Wattam, Stephen, Paul Rayson, Marc Alexander and Alistair Baron. 2014. 'Experiences with parallelisation of an existing NLP pipeline: tagging Hansard'. Proceedings for the Ninth International Conference on Language Resources and Evaluation (LREC): 4093-4096. 